\title{
EFFECT OF GHRELIN AND RATION COMPOSITION ON MILK OUTPUT AND FEED INTAKE IN RABBITS
}

\author{
Dorota Kowalska ${ }^{1}$, Mariusz Pietras ${ }^{2}$, Paweł Bielański ${ }^{1}$ \\ ${ }^{1}$ Department of Animal Genetic Resources Conservation, \\ ${ }^{2}$ Department of Animal Nutrition and Feed Science, \\ National Research Institute of Animal Production, 32-083 Balice n. Kraków, Poland
}

\begin{abstract}
The aim of the study was to determine plasma ghrelin concentrations in rabbits. The first part of the experiment focused on plasma ghrelin concentrations in does which were at different physiological stages and received diets with different fat contents. Plasma ghrelin levels were determined in 3-month-old rabbits after 12-hour feed withdrawal and 60 minutes after feed intake. The second part of the experiment investigated the effect of exogenous ghrelin administered to dams on the course of the lactation and weight gains of young rabbits from birth to weaning. The results of the first experiment show that plasma ghrelin levels vary according to the physiological stage of the does. The addition of $2 \%$ rapeseed oil to the diet of the does had an inhibitory effect on ghrelin secretion by significantly decreasing its plasma levels. Analysis of plasma ghrelin levels in 3-month-old rabbits subjected to feed withdrawal and following food intake revealed that ghrelin secretion increased when both oil-enriched and unsupplemented diets were fed after feed withdrawal. Ghrelin levels began to decline postprandially. The second part of the experiment demonstrated that ghrelin administered intraperitoneally to the lactating does had an effect on the milk output of the does and thus on the weight gains of the young rabbits.
\end{abstract}

Key words: rabbit, ghrelin, feeding, lactation

Ghrelin is a 28-amino acid peptide, secreted by endocrine cells of the gut and hypothalamic neurons. Ghrelin receptors are found in different brain structures, in the pancreas, kidneys, adipose tissue, ovaries, cardiac muscle and blood vessels (Rak and Gregoraszczuk, 2009; Suzuki et al., 2010). Under physiological conditions, ghrelin stimulates growth hormone $(\mathrm{GH})$ release, and increases appetite and food intake by stimulating neuropeptide Y (NPY) cells and Agouti-related (AgRP) protein in the hypothalamic arcuate nucleus (Castaneda et al., 2010). About $60-70 \%$ of ghrelin in the blood is released from oxyntic cells (X/A-like cells) in the body and fundus of the stomach, which are closely associated with a network of capillaries (Kojima et al., 1999). Ghrelin is not released into the GIT lumen. The concentration of ghrelin 
in the bloodstream depends on the state of nutrition. Plasma ghrelin concentration rises during fasting (with the highest concentrations observed immediately before the meal), and decreases 90 min postprandially (Cummings et al., 2001). In animals, ghrelin stimulates the release of the adrenocorticotropic hormone (ACTH), prolactin (PRL), cortisone and aldosterone, while inhibiting the secretion of the thyroidstimulating hormone (TSH) (Woliński et al., 2006). The mode of action of ghrelin has received the most study in rats and pigs. Nakahara et al. (2003) showed the effect of exogenous ghrelin administered to lactating rats on the course of lactation and growth of the young. Ghrelin stimulated milk synthesis by increasing the mammary gland blood flow. Analogous observations were made for the effect of ghrelin on stimulating the growth of piglets born to mothers that received ghrelin in early lactation.

In birds, the first ghrelin research concerned its stimulating effect on growth hormone release. The effects of ghrelin on food intake by birds are inconsistent because the results varied according to species, mode of peptide administration, and dose size (Saito et al., 2002). Ocłoń and Pietras (2007, 2011) showed that in 42-day-old chickens, 24-hour feed deprivation caused a considerable increase in ghrelin concentration in the pituitary, blood plasma, stomach and adrenals. These results agree with the earlier report of Kaiya et al. (2007) that fasting has a positive effect not only on ghrelin concentration but also on the GHRL gene expression in the avian stomach. The significant increase in the pituitary concentration of ghrelin was evidence that birds exposed to fasting stress mobilize ghrelin reserves in both the peripheral and the central nervous system (CNS). Similar changes in the CNS were also found in rats deprived of feed.

Geelissen et al. (2006) demonstrated that peripheral injection of $1 \mathrm{nmol}$ ghrelin/100 g b.w. inhibited food intake in 7-day-old chickens, but Kaiya et al. (2007) reported no statistically significant changes in the amount of feed intake by chickens injected intravenously with 500 pmol of ghrelin. Ocłoń and Pietras (2011) confirmed the anorexigenic nature of ghrelin in 7-day-old chickens. The administered ghrelin doses significantly decreased the amount of feed intake, which allows a conclusion that peripheral ghrelin (administered intravenously or intraperitoneally) crosses the blood-brain barrier and penetrates the solitary tract nucleus to the central nervous system, thus inhibiting feed intake.

Because only a few studies in rabbits concerned ghrelin, this study was undertaken to determine plasma ghrelin concentrations in differently fed rabbits of different ages and at different physiological states. The effect of ghrelin, administered intraperitoneally to pregnant and first lactation does, on the amount of milk secreted and weight gains of young rabbits was determined.

\section{Material and methods}

Subjects were New Zealand White (NZW) rabbits, a typical meat breed used in farming. Females of the foundation stock were caged individually on deep litter in 
a confined, unheated facility, and young rabbits were kept in tiered wire-mesh cages with 4 animals of the same sex per cage.

In the first part of the experiment, animals were assigned to two feeding groups. Rabbits from group I were fed complete pelleted diet consisting of dried lucerne, wheat bran, ground barley, ground maize, soybean meal, powdered milk, ground limestone, $\mathrm{NaCl}$ and a mineral-vitamin mixture. The diet for group II was supplemented with $2 \%$ rapeseed oil.

The compound feeds were analysed for the content of dry matter, crude protein, crude fat, crude ash, crude fibre, organic matter and $\mathrm{N}$-free extractives. The determinations were performed according to AOAC procedures (1990).

Two experiments were performed. The first experiment was designed to examine changes in the plasma concentration of endogenous ghrelin in female rabbits which were at different physiological stages and received different diets, as well as in young rabbits after 12-hour feed withdrawal and 60 minutes after feed intake. The animals were divided into groups according to the following scheme:

Ten females fed unsupplemented diet and 10 females fed oil-enriched diet (blood collection 60 minutes after feed intake):

1. intended for reproduction at 5 months of age (before mating),

2. in the first week of pregnancy,

3 . in the third week of pregnancy,

4. after kindling (day 2).

Young rabbits (10 animals receiving unsupplemented diet and 10 animals fed oil-enriched diet):

1. at the age of 3 months, after 12-hour feed withdrawal,

2 . at the age of 3 months, 60 minutes after feed intake.

The does were fed rationed amounts of feed (150 g) during the resting period and ad libitum during pregnancy and rearing of young to 35 days of age. From weaning (day 35) to 90 days of age, young rabbits were fed ad libitum. The does and the young rabbits received different diets for 3 weeks before the experimental period.

Two $\mathrm{ml}$ of blood was drawn from the marginal vein of the ear of each animal during the periods mentioned above. The blood was centrifuged in a type 320 Microcentrifuge for 3 minutes. Blood samples were frozen at $-20^{\circ} \mathrm{C}$ until further analysis. Plasma ghrelin levels were determined by radioimmunoassay using a commercial RIA kit (Linco Research, ST, Charles, MO; intra assay variation of 9.5\%, sensitivity of $7.8-2000 \mathrm{pg} / \mathrm{ml})$.

The aim of the second experiment was to determine the effect of giving exogenous ghrelin to pregnant and lactating does on the growth rate of rabbits from birth to 35 days of age. Two groups of females (10 does per group) were established, which were mated at 5 months of age. In the first week of pregnancy (day 6) and at 10 days of lactation, each doe from the experimental group was given intraperitoneal injections of endogenous ghrelin (3 $\mathrm{mcg} / \mathrm{kg} \mathrm{b}$.w.) dissolved in physiological solution to $1 \mathrm{ml}$ volume (CALBIOCHEM, Ghrelin, Rat, Mouse, Synthetic). On the same days, the control does were injected intraperitoneally with a placebo $(1 \mathrm{ml}$ of physiological solution). Litters of the does were standardized to 6 animals to exclude the effect of litter size on daily gains of the young. Young rabbits were weighed every day at the 
same time $(8: 00 \mathrm{am})$ from birth to 35 days of age to determine daily gains, on the basis of which the does' milk output was determined.

The results were analysed statistically with analysis of variance and Duncan's D-test, using Statistica 7 software.

\section{Results}

Basic nutrient content of the samples of complete feed mixtures (\%) are shown in Table 1. The basal mixture had a moderate level of nutrients. Does were able to correct possible fibre deficiency by eating straw bedding. The rapeseed oil supplement caused crude fat to increase from 2.95 to $4.92 \%$. In both feed mixtures, the level of protein was similar (16.79\% in group I, $16.77 \%$ in group II).

Table 1. Results of analysis of basic nutrients in samples of complete feed mixtures (\%)

\begin{tabular}{l|c|c|c|c|c|c|c}
\hline Group & Dry matter & Crude ash & $\begin{array}{c}\text { Organic } \\
\text { matter }\end{array}$ & $\begin{array}{c}\text { Crude } \\
\text { protein }\end{array}$ & Crude fat & Crude fibre & N-free extractives \\
\hline I & 89.01 & 6.07 & 82.94 & 16.79 & 2.95 & 8.93 & 54.27 \\
II & 89.63 & 6.87 & 82.76 & 16.77 & 4.92 & 7.38 & 53.69 \\
\hline
\end{tabular}

When feeding the basal diet, highly significant differences were found in plasma ghrelin levels between the does 1 and 3 weeks pregnant and after kindling, and significant differences between 5-month-old does before mating and the kindled group. When diets enriched with $2 \%$ rapeseed oil were fed, no statistically significant differences were observed (Tables 2 and 3).

Table 2. Plasma ghrelin levels in rabbit does fed complete basal pellets at different physiological states

\begin{tabular}{lc}
\hline \multicolumn{1}{c|}{ Physiological states } & Ghrelin level (pg/ml) \\
\hline 5-month-old does before mating & $218.12 \pm 55.2 \mathrm{a}$ \\
Does 1 week pregnant & $241.75 \pm 48.6 \mathrm{~A}$ \\
Does 3 weeks pregnant & $169.9 \pm 37.7 \mathrm{~B}$ \\
Kindled does & $158.75 \pm 45.6 \mathrm{Bb}$ \\
\hline
\end{tabular}

A, B - values in column with different letters differ highly significantly $(\mathrm{P} \leq 0.01)$.

$\mathrm{a}, \mathrm{b}$ - values in column with different letters differ significantly $(0.01<\mathrm{P} \leq 0.05)$.

Table 3. Plasma ghrelin levels in rabbit does fed complete pellets supplemented with $2 \%$ rapeseed oil at different physiological states

\begin{tabular}{lc}
\hline \multicolumn{1}{c|}{ Physiological states } & Ghrelin level (pg/ml) \\
\hline 5-month-old does before mating & $176.50 \pm 46.3$ \\
Does 1 week pregnant & $181.87 \pm 61.3$ \\
Does 3 weeks pregnant & $113.25 \pm 81.3$ \\
Kindled does & $158.62 \pm 54.0$ \\
\hline
\end{tabular}


Comparison of plasma ghrelin levels in rabbits at different physiological states, supplemented with $2 \%$ rapeseed oil or not, revealed significant differences for the group of 5-month-old rabbits and for does in the first and third weeks of pregnancy. In the group of kindled does, the addition of oil to the diet had no effect on plasma ghrelin levels (Table 4).

Table 4. Plasma ghrelin levels in rabbit does fed diets with and without rapeseed oil at different physiological states

\begin{tabular}{l|c|c}
\hline \multirow{2}{*}{\multicolumn{1}{c}{ Physiological states }} & \multicolumn{2}{c}{ Ghrelin level (pg/ml) } \\
\cline { 2 - 3 } & diet without added fat & diet with added fat \\
\hline 5-month-old does before mating & $218.12 \pm 55.2 \mathrm{a}$ & $176.50 \pm 46.3 \mathrm{~b}$ \\
Does 1 week pregnant & $241.75 \pm 48.6 \mathrm{a}$ & $181.87 \pm 61.3 \mathrm{~b}$ \\
Does 3 weeks pregnant & $169.87 \pm 37.7 \mathrm{a}$ & $113.25 \pm 81.3 \mathrm{~b}$ \\
Kindled does & $158.75 \pm 45.6$ & $158.62 \pm 54.0$ \\
\hline
\end{tabular}

A, B - values in rows with different letters differ highly significantly $(\mathrm{P} \leq 0.01)$.

$\mathrm{a}, \mathrm{b}-$ values in rows with different letters differ significantly $(0.01<\mathrm{P} \leq 0.05)$.

Table 5. Plasma ghrelin levels in 3-month-old rabbits after feed withdrawal and directly after feed ingestion

\begin{tabular}{lcc}
\hline \multicolumn{1}{c|}{ Rabbits: } & Diet with added fat & Diet without added fat \\
\hline aged 3 months, after feed withdrawal & $189.37 \pm 63.5 \mathrm{a}$ & $195.28 \pm 26.7 \mathrm{~A}$ \\
aged 3 months, after feed intake & $157.50 \pm 22.3 \mathrm{~b}$ & $140.28 \pm 24.69 \mathrm{~B}$ \\
\hline
\end{tabular}

A, $\mathrm{B}$ - values in columns with different letters differ highly significantly $(\mathrm{P} \leq 0.01)$.

$\mathrm{a}, \mathrm{b}-$ values in columns with different letters differ significantly $(0.01<\mathrm{P} \leq 0.05)$.

Table 5 presents plasma ghrelin levels, analysed after 12-hour feed deprivation and 60 minutes postprandially, in rabbits aged 3 months. In both groups of animals, ghrelin levels were higher after feed deprivation and decreased by $16.8 \%$ (oil-enriched diet) to $28.2 \%$ (unsupplemented diet) after feeding. Highly significant $(\mathrm{P} \leq 0.01)$ differences in the ghrelin level were found between feed-deprived and fed rabbits when animals received basal (unsupplemented) diet. For the oil-enriched diet, the differences were at a level of $\mathrm{P} \leq 0.05$.

Table 6. Body weight of young rabbits on different days of lactation $(\mathrm{g})$

\begin{tabular}{l|c|c|c|c}
\hline \multirow{2}{*}{ Group } & \multicolumn{5}{|c}{ Day of age } \\
\cline { 2 - 5 } & 1 & 10 & 21 & 35 \\
\hline $\mathrm{I}$ & $56.87 \pm 10.9$ & $142.76 \pm 28.9$ & $252.74 \pm 28.0 \mathrm{~A}$ & $592.18 \pm 89.5 \mathrm{a}$ \\
$\mathrm{II}$ & $53.55 \pm 10.5$ & $145.08 \pm 28.1$ & $313.57 \pm 33.1 \mathrm{~B}$ & $686.26 \pm 29.0 \mathrm{~b}$ \\
\hline
\end{tabular}

$\mathrm{A}, \mathrm{B}$ - values in columns with different letters differ highly significantly $(\mathrm{P} \leq 0.01)$.

$\mathrm{a}, \mathrm{b}-$ values in columns with different letters differ significantly $(0.01<\mathrm{P} \leq 0.05)$

Giving ghrelin before kindling had no significant effect on the milk output of the does (Table 6). No significant differences in body weight were found between the analysed groups of young rabbits to 10 days of age. Differences between the body 
weight of young rabbits from both groups were found at 21 days (highly significant) and 35 days (significant), which shows a relationship between the administration of ghrelin during lactation and milk output of the does.

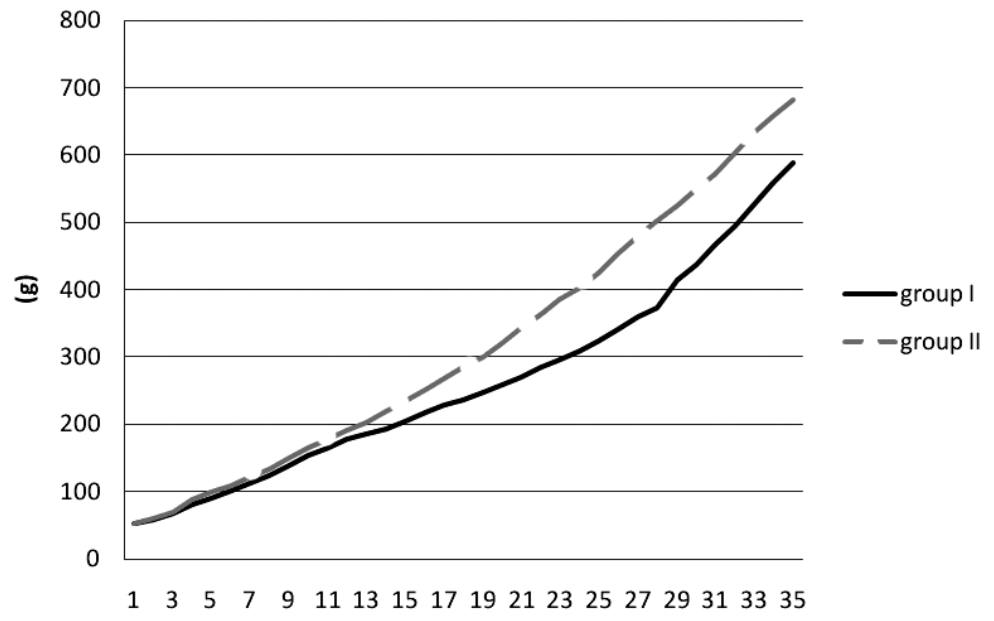

Figure 1. Mean body weight per young rabbit from birth to 35 days of age (g)

Figure 1 presents body weight of young rabbits during lactation of the does, i.e. from days 1 to 35 . The highest effect on the milk output of the does was exerted by ghrelin administration during lactation.

During the period from mating to weaning of the young (day 66), feed intake by the does averaged $10.69 \mathrm{~kg}$ (161 g/day) for the control group and $12.29 \mathrm{~kg}$ (186 $\mathrm{g}$ /day) for the experimental group.

\section{Discussion}

Shiiya et al. (2002) and Nakagawa et al. (2002) attributed the inhibition of ghrelin secretion to a high-fat diet. Our study confirmed this hypothesis for all animals except the newly kindled does. In the other groups, the addition of oil significantly reduced ghrelin levels.

Ghrelin concentration in ad libitum fed birds (quail, chickens) was shown to increase as much as 5-fold after 24-hour fasting, and subsequent feeding restored the initial level of the peptide (Shousha et al., 2005). This is because restriction in feed availability reduces the number of ghrelin-immunopositive cells in the gizzard, which is paralleled by an increase in the plasma peptide concentration and its increased secretion from the gizzard. In rabbits, the highest ghrelin concentration occurred on an empty stomach, and decreased 60 minutes after feed intake, by $16.8 \%$ for oil-supplemented feeds and by $28.2 \%$ for unsupplemented feeds. Dytfeld and 
Pupek-Musialik (2005) report that unlike insulin, the level of ghrelin decreases after food intake, which shows that ghrelin may provide a direct stimulus for food intake. Ghrelin concentration decreases mainly in response to carbohydrates, followed by protein and fat (Delzenne et al., 2010). In rats, Nakazato et al. (2001) showed that neutralization of ghrelin by specific antibodies inhibits the need for food.

The highest ghrelin levels, both when feeding basal and oil-supplemented diet, were found in does in the first week of pregnancy. Research with pregnant female rats showed increased secretion of ghrelin during gestation. Its presence in the blood serum of neonates suggests that it may affect fetal growth and maturation during intrauterine development (Cortelazzi et al., 2003).

The higher milk output of females stimulated body weight gain in young rabbits. Studies with other groups of animals demonstrated that exogenous ghrelin administered during lactation stimulates milk synthesis by increasing the mammary gland flow rate. In rats, Nakahara et al. (2003) showed that appetite and milk production in ghrelin-supplemented dams increased and the weight of their offspring was higher than in the control group. Likewise, body weight gain was stimulated in pups born to bitches administered with ghrelin in early lactation. Unfortunately, it was observed that the ghrelin-induced increase in body weight takes place mainly through adipose tissue deposition, with no changes in the skeletal and muscular systems (Tschöp et al., 2000).

In the does given intraperitoneal injections of ghrelin, appetite was found to increase during pregnancy and after kindling. Feed intake increased by $15 \%$ on average. Sugino et al. (2002) showed that ghrelin administered to mammals stimulated feed intake, regardless of the mode of its administration. The main mechanism responsible for the orexigenic effect of ghrelin involves increased synthesis of NPY (which increases appetite), AgRP (which responds to signals about the loss and increase of the body's energy status), and orexins (which regulate feed ingestion and hormone release) (Nakazato et al., 2001).

The results of the first experiment indicate that plasma ghrelin levels vary according to the physiological stage of the does. The addition of $2 \%$ rapeseed oil to the diet of the does had an inhibitory effect on ghrelin secretion by significantly decreasing its plasma levels. Analysis of plasma ghrelin levels in 3-month-old rabbits subjected to feed withdrawal and following food intake revealed that ghrelin secretion increased when both oil-enriched and unsupplemented diets were fed after feed withdrawal. Ghrelin levels began to decline postprandially. The second part of the experiment demonstrated that ghrelin administered intraperitoneally to the lactating does had an effect on the milk output of the does and thus on the weight gains of the young rabbits.

\section{References}

A O A C (1990). Official Methods of Analysis. Heldrich K. (Ed). Association of Official Analytical Chemists. 15th Edition, Arlington, VA, USA.

Cas t a n e d a T.R., T ong J., D a t t a R., C u 11 e r M., T s c hö p M.H. (2010). Ghrelin in the regulation of body weight and metabolism. Frontiers in Neuroendocrinol., 31: 44-60. 
Cortelazzi D., Cappiello V., Morpurgo P.S., Ronzoni S., Nobile De Santis M.S., C e t in I., B e c k-P e c c o z P., S p a d a A. (2003). Circulating levels of ghrelin in human fetuses. Eur. J. Endocrinol., 149, 2: 111-116

$\mathrm{Cu} \mathrm{m} \mathrm{m}$ in g s D.E. (2001). Ghrelin and the short- and long-term regulation of appetite and body weight. Physiol. Behav., 89: 71-84.

Delzenne N., Blundell J., Brouns F., Cunningham K., De Graaf K., Erkner A., Lluch A., Mars M., Peters H.P., Westertero-P lantenga M. (2010). Gastrointestinal targets of appetite regulation in humans. Obes. Rev., 11: 234-250.

Dytfeld J., Pupek-Musialik D. (2005). Gut hormones regulating satiety: the gut-brain axis. Endokrynologia. Otyłość i Zaburzenia Przemiany Materii, 1, 2: 24-30.

Geelissen S.M., Swennen Q., Geyten S.V., Kühn E.R., Kaiya H., Kangawa K., Decuyoere E., B uy s e J., D arras V.M. (2006). Peripheral ghrelin reduces food intake and respiratory quotient in chicken. Domest. Anim. Endocrinol., 30: 108-116.

Ka i y a H., S a i to E.S., T a ch ib an a T., Furus e M., K angaw a K. (2007). Changes in ghrelin levels of plasma and proventriculus and ghrelin mRNA of proventriculus in fasted and refed layer chicks. Domest. Anim. Endocrinol. 32: 447-459.

K oj i m a M., H o s o d a H., D a te Y., N a ka z a t o M., M a t s u o H., K a n g a w a K. (1999). Ghrelin is growth-hormone-releasing acylated peptide from stomach. Nature, 402: 656-660.

Nakagawa E., Naga y a N., Okumura H. (2002). Hyperlycaemia suppresses the secretion of ghrelin, a novel growth-hormone-releasing peptide: responses to the intravenous and oral administration of glucose. Clin. Sci., 103: 325-328.

$\mathrm{Nak}$ ahara K, Hay a shida T, Nakazato M. Kojima M, Hos oda H, Kangawa K, Mur a k a mi N. (2003). Effect of chronic treatments with ghrelin on milk secretion in lactating rats. Biochem. Biophys. Res. Commun., 303 (3): 751-755.

$\mathrm{Nakazato}$ M., Murakami N., Date Y. (2001). A role for ghrelin in the central regulation of feeding. Nature, 409: 194-198.

O cłoń E., P i e tr a s M. (2007). Ghrelin/Obestatin: a new mechanism for appetite control? Med. Wet., 63: 1139-1141.

O cłoń E., P i e tra s M. (2011). Peripheral ghrelin inhibits feed intake through hypothalamo-pituitaryadrenal axis-dependent mechanism in chicken. J. Anim. Feed Sci., 20: 118-130.

R a k A., Greg or a s z c zuk E. (2009). Modulatory effect of ghrelin in prepubertal porcine ovarian follicles. J. Physiol. Pharmacol., 59: 781-793.

Saito S., Takagi T., Nakan ishi T., Sashihara K., Furuse M. (2002). Ghrelin activates behavior of neonatal chicks in a short period of post-intracerebroventricular injection. J. Appl. Anim. Res., 22: 33-41.

Shi i y a T., Nakazato M., Mizuta M. (2002). Plasma ghrelin levels in lean and obese humans and the effect of glucose on ghrelin secrection. J. Clin. Endocrinol. Metab., 87: 240-244.

Shousha S., Nakahara K., Koj i ma M., Mi y a za to M., Hos od a H., Kangaw a K., M u r a k a m i N. (2005). Different effects of peripheral and central ghrelin on regulation of food intake in the Japanese quail. Gen. Comp. Endocrinol., 141: 178-183.

Sugino T., Hasegawa Y., Kikkawa Y., Yamaura J., Yamagishi M., Kurose Y., Kojima M., Kangawa K., Terashima Y.A. (2002). A transient ghrelin surge occurs just before feeding in a scheduled meal-fed sheep. Biochem. Biophys. Res. Commun., 295: $255-260$.

Suzuki K., S imps on K.A., M inni on J.S., Shillito J.C., B lo o m S.R. (2010). The role of gut hormones and the hypothalamus in appetite regulation. Endocr. J., 57: 372-395.

T s chöp M., S miley D.L., He i man M.L. (2000). Ghrelin induces adiposity in rodents. Nature, 407: 908-13.

Wolińs ki J., Kotunia A., Rom a now i c z K., S łu pe c ka M., Zabielski R. (2006). Ghrelin is present in swine colostrum, milk and plasma. Regul. Peptides, 135, p. 167. 


\section{DOROTA KOWALSKA, MARIUSZ PIETRAS, PAWEŁ BIELAŃSKI}

\section{Wpływ greliny i składu dawki na mleczność i pobieranie paszy u królików}

\section{STRESZCZENIE}

Prowadzone badania miały na celu oznaczenie koncentracji greliny w plazmie krwi królików. Pierwsza część eksperymentu dotyczyła koncentracji greliny w plazmie samic znajdujących się w różnym okresie fizjologicznym, przy żywieniu mieszankami paszowymi o różnej zawartości tłuszczu. Badano poziom greliny w plazmie krwi 3-miesięcznych królicząt po 12-godzinnej głodówce oraz po 60 minutach od podania paszy. Druga część eksperymentu dotyczyła wpływu egzogennej greliny podawanej matkom na przebieg laktacji oraz przyrosty królicząt od urodzenia do odsadzenia. Uzyskane wyniki pierwszego eksperymentu wskazują, że poziom greliny w plazmie krwi jest różny w zależności od okresu fizjologicznego, w jakim znajdują się królice. Wprowadzenie do mieszanki paszowej dla samic $2 \%$ dodatku oleju rzepakowego wpływa na inhibicję sekrecji greliny, istotnie obniżając jej ilość w plazmie krwi. Badając poziom greliny w plazmie krwi 3-miesięcznych królików po przegłodzeniu i po jedzeniu stwierdzono wyższe wydzielanie greliny zarówno przy podawaniu mieszanki natłuszczanej, jak i nienatłuszczanej po przegłodzeniu. Po jedzeniu poziom greliny zaczyna spadać. Druga część eksperymentu wykazała, że grelina podawana samicom dootrzewnowo w trakcie laktacji miała wpływ na mleczność samic, a tym samym na przyrosty młodych królicząt. 